\title{
EFEK MODERASI KEPERCAYAAN POLITIK TERHADAP HUBUNGAN ANTARA RELIGIUSITAS ISLAM DAN INTOLERANSI POLITIK
}

\author{
Ananda Zhafira* \\ Fakultas Psikologi, Universitas Indonesia, Depok \\ *Email: anandazha@gmail.com
}

\begin{abstract}
Abstrak
Penelitian ini merupakan studi kuantitatif yang bertujuan untuk mengetahui hubungan antara religiusitas Islam dan intoleransi politik dan efek moderasi kepercayaan politik terhadap hubungan dua variabel tersebut. Intoleransi politik diprediksi memiliki hubungan positif dengan intoleransi politik di mana kepercayaan politik dapat memperkuat hubungan keduanya. Intoleransi politik diukur dengan Political Intolerance Scale yang dikembangkan oleh Sullivan, Marcus, Feldman, dan Piereson (1981) sementara itu religiusitas Islam diukur dengan Muslim Religiosity Scale yang disusun oleh El-Menouar (2014). Kepercayaan politik diukur dengan Citizen Trust in Government Organizations Scale yang dikembangkan oleh Grimmelikhuijsen dan Knies (2015). Responden penelitian ini merupakan 841 orang mahasiswa di Indonesia yang beragama Islam dan dijaring secara daring. Hasil penelitian ini menunjukkan bahwa religiusitas Islam berkorelasi positif dan signifikan dengan intoleransi politik. Sementara itu, kepercayaan politik tidak berkontribusi sebagai moderator terhadap hubungan religiusitas Islam dan intoleransi politik.
\end{abstract}

Kata kunci: intoleransi politik, kepercayaan politik, religiusitas Islam

\begin{abstract}
This quantitative study was aimed to examine the correlation between Muslim religiosity and political intolerance whereas political trust as moderator variable. Political intolerance was measured by Political Intolerance Scale which developed by Sullivan at al., (1981) while Muslim religiosity was measured by Muslim Religiosity Scale which developed by ElMenouar (2014). Political trust was measured by Citizen Trust in Government Organizations Scale which developed by Grimmelikhuijsen and Knies (2015). Respondents of this study were 841 Muslim college students. Results indicated that there is significant positive correlation between Muslim religiosity and political intolerance. Meanwhile, political trust was not contributing as moderator variable towards the correlation between Muslim religiosity and political intolerance.
\end{abstract}

Keywords: political intolerance, political trust, Muslim religiosity

\section{Pendahuluan}

Sebuah negara demokrasi dapat terpecah belah akibat konflik yang sengit tetapi selama penduduknya mendukung asas-asas demokrasi seperti hak untuk berbicara di ruang publik hingga partisipasi dalam kegiatan politik, negara demokrasi dapat mempertahankan stabilitas sosial dan politiknya (Sullivan, Piereson, \& Marcus, 1979). Untuk memastikan bahwa dukungan terhadap asas-asas demokrasi berlangsung optimal, diperlukan masyarakat yang dapat memberikan hak-hak politik sekalipun 
kepada kelompok yang tidak disukai (Sullivan dkk., 1979). Di sisi lain, temuan Eisenstein dan Clark (2017) menunjukkan bahwa masyarakat di negara-negara demokrasi sulit untuk mewujudkan asasasas demokrasi akibat tingginya intoleransi terhadap kelompok yang tidak disukai masyarakat.

Indonesia termasuk negara demokrasi yang sedang menghadapi isu toleransi. Hal ini ditunjukkan oleh hasil survei yang dilakukan oleh International NGO Forum on Indonesian Development (INFID) dan jaringan GUSDURian pada Agustus-Oktober 2016 (Tirto.id, 2017) bahwa terdapat 90.000 akun media sosial setiap bulannya yang menyebarkan sikap intoleransi melalui pesan radikal dan ekstremisme. Survei ini menunjukkan bahwa dalam kurun waktu tiga bulan terdapat lebih dari 200.000 pesan intoleransi yang tersebar melalui platform media sosial seperti Facebook dan Twitter.

Survei lain yang berjudul "Potensi Intoleransi dan Radikalisme Sosial Keagamaan di Kalangan Muslim Indonesia" dilakukan oleh Wahid Foundation dan Lembaga Survei Indonesia (LSI) pada Maret-April 2016 (Wahid Foundation, 2016) terhadap 1.520 responden berusia di atas 17 tahun menunjukkan bahwa $59,9 \%$ responden memiliki kelompok yang dibenci, yaitu kelompok dengan latar belakang nonmuslim, Tionghoa, komunis, dan lainnya. Dari 59,9\% responden, $92,2 \%$ di antaranya tidak setuju apabila anggota kelompok yang mereka benci menjadi pejabat pemerintahan di Indonesia.

Sikap menentang kebebasan sipil dalam kegiatan politik merupakan bentuk adanya intoleransi politik dalam praktik demokrasi. Intoleransi politik diartikan sebagai keengganan untuk memberikan hak-hak sipil pada kelompok yang tidak disukai (Sullivan dkk., 1979). Dalam fenomena ini, kelompok yang tidak disukai dan ditentang hak-hak politiknya merupakan orang-orang de-ngan latar belakang kelompok berbeda atau kelompok luar (outgroup). Dengan demikian, hasil survei sebelumnya yang dilakukan Wahid Foundation dan LSI mengindikasikan adanya sikap intoleransi politik terhadap kelompok yang tidak disukai atau dibenci.

Dalam studi-studi terdahulu, intoleransi politik dapat dijelaskan melalui variabel individual seperti kekakuan psikologis (psychological rigidity) dan dogmatisme (Sullivan dkk., 1981), intoleransi terhadap ambiguitas (McClosky \& Brill, 1983), openness to experience yang rendah (Marcus, Sullivan, TheissMorse, \& Wood, 1995), otoritarianisme (Altemeyer, 1988), dan persepsi terhadap ancaman sebagai predisposisi maupun perspepsi ancamana terhadap kelompok yang spesifik (Marcus dkk., 1995; Sullivan dkk., 1981). Penelitian yang dilakukan oleh Sullivan dkk. (1981) menunjukkan bahwa variabel-variabel individual memiliki pengaruh yang kuat terhadap intoleransi politik walaupun pengaruhnya tidak langsung.

Temuan Gibson (2010) menunjukkan bahwa religiusitas memiliki kaitan dengan peningkatan intoleransi politik. Gibson menyatakan bahwa orang-orang yang religius lebih intoleran bukan karena mereka lebih merasa terancam oleh lawan politiknya, bukan pula karena mereka lebih dogmatis atau tidak mendukung proses demokrasi dibanding kelompok masyarakat lainnya. Intoleransi politik pada kelompok religius terjadi semata-mata disebabkan oleh semakin besar keterlibatan seseorang dalam agamanya (Gibson, 2010). Namun, penelitian Gibson (2010) belum menjabarkan lebih lanjut bagaimana agama menjadi prediktor dari intoleransi politik. Oleh karena itu, masih terdapat pertanyaan apakah ada faktor lain yang dapat mempengaruhi hubungan religiusitas dan intoleransi politik. Penelitian lain yang menelusuri hubungan antara agama dan intoleransi politik juga dilakukan oleh Eisenstein (2006) yang menemukan bahwa salah satu faktor yang diidentifikasi dapat memprediksi intoleransi politik adalah religious commitment atau komitmen ter- 
hadap agama. Eisenstein (2006) menemukan bahwa komitmen terhadap agama (religious commitment) memiliki hubungan yang positif dengan intoleransi politik.

Penelitian terdahulu mengenai intoleransi yang dilakukan oleh Stouffer (1955) menjabarkan bahwa ketika komitmen terhadap agama seseorang menurun (dengan melihat status agama seseorang), maka toleransi akan meningkat. Dalam berbagai studi, agama dalam bentuk belief (keyakinan), attitude (sikap), dan behavior (tingkah laku) merupakan prediktor terhadap intoleransi politik (Stouffer, 1955; Eisenstein, 2006; Eisenstein \& Clark, 2014). Berdasarkan studi-studi itu dapat disimpulkan bahwa komitmen dalam beragama dapat menjadi salah satu faktor yang berperan dalam menentukan intoleransi politik.

Eisenstein dan Clark (2014) juga menemukan bahwa faktor agama yang terdiri dari religious tradition (ajaran agama) dan doctrinal orthodoxy (doktrin awal) dapat menjadi prediktor intoleransi politik secara tidak langsung. Eisenstein dan Clark (2014) juga menemukan bahwa trust atau kepercayaan merupakan variabel yang paling kuat dalam memediasi hubungan agama dan intoleransi politik. Agama juga sering kali dikaitkan dengan ketidaksukaan terhadap nilai-nilai yang mendukung keterbukaan terhadap perubahan dan otonomi (Saroglou, Delpierre, \& Dernelle, 2004).

Temuan Eisenstein, Clark, dan Clark (2014) menunjukkan bahwa komitmen seseorang terhadap agama dan doktrin kepercayaan agama dapat memprediksi toleransi politik. Eisenstein, Clark, dan Clark juga menambahkan bahwa trust (kepercayaan) memiliki hubungan yang searah dengan toleransi politik. Kepercayaan merupakan variabel yang dapat berperan terhadap hubungan agama dan toleransi politik. Apabila dikaitkan dengan konteks toleransi dalam proses politik, seseorang yang memiliki kepercayaan tinggi akan cenderung lebih toleran.
Kepercayaan terhadap pemerintahan maupun institusi politik dapat disebut sebagai kepercayaan politik (Newton, 2001). Pemerintah atau pejabat publik yang memperoleh kepercayaan dari rakyatnya dipersepsikan bahwa mampu untuk berfungsi secara efektif. Dalam menjalankan sistem demokrasi, kepercayaan politik merupakan hal yang penting karena pejabat publik dipilih langsung oleh rakyat (Nye, Zelikow, \& King, 1997; Levi \& Stoker 2000; Nannestad, 2008).

Kepercayaan politik penting karena demokrasi didasarkan pada mekanisme institusi yang memastikan bahwa politisi mempunyai sikap yang dapat dipercaya (Newton, 2001). Dalam beberapa tahun terakhir, riset-riset intoleransi politik lebih banyak berfokus pada variabel individual (Hinckley, 2010; Hazama, 2010, Haas \& Cunningham, 2014). Padahal di negaranegara demokrasi yang plural seperti Indonesia, agama merupakan salah satu hal penting yang dapat mempengaruhi perilaku politik termasuk toleransi politik.

Penelitian sebelumnya menemukan bahwa agama memiliki korelasi dengan kecenderungan kepercayaan seseorang dalam berbagai aspek, tidak hanya sebatas dalam hubungan interpersonal tetapi juga terhadap pemerintahan (Beyerlein \& Hipp, 2006; Welch, Sikkink, Sartain \& Bond, 2004). Berdasarkan temuan studi-studi terdahulu dan penjelasan fenomena intoleransi di Indonesia, maka variabel agama dan kepercayaan politik dapat menjadi prediktor dari intoleransi politik. Sementara itu, di Indonesia sendiri agama dianggap sebagai identitas yang penting. Oleh karena itu, diperlukan studi yang melihat faktor-faktor yang memprediksi intoleransi politik di Indonesia. Studi ini akan melihat prediktor dari intoleransi politik, yaitu religiusitas Islam dan kepercayaan politik sebagai variabel yang dapat mempengaruhi kekuatan hubungan antara religiusitas Islam dengan intoleransi politik. 
Intoleransi Politik. Intoleransi politik yang dimaksud dalam studi ini adalah keengganan individu untuk membiarkan ide-ide atau kelompok yang tidak disukai untuk berpartisipasi dalam aktivitas politik (Sullivan dkk., 1981). Aktivitas politik yang dimaksud dalam konteks intoleransi politik adalah mulai dari partisipasi untuk memilih dalam pemilihan umum hingga mencalonkan diri sebagai pemimpin politik. Intoleransi politik terlihat ketika terdapat kelompok yang menolak ekspresi ide atau pemikiran lain yang berlawanan dengan keyakinannya (Gibson \& Bingham, 1982). Rezim yang intoleran seperti orang yang intoleran, merupakan sistem yang memperbolehkan pemikiran yang menantang atau berseberangan dengannya (Sullivan dkk., 1979; Protho \& Grigg, 1960).

Bentuk kegiatan atau aktivitas politik yang perlu ditolerir masih menjadi perdebatan pada studi-studi sebelumnya. Penelitian Stouffer (1955) yang paling awal yang mengukur intoleransi politik fokus tidak hanya pada hak untuk mengemukakan pendapat dan berserikat di ruang publik tetapi juga hak untuk tidak dikucilkan karena afiliasi tertentu. Studi kontemporer mengenai intoleransi maupun toleransi politik memperluas makna aktivitas politik yang meliputi hak untuk menjadi kandidat dalam pemilihan umum, hak untuk berbicara, hak untuk unjuk rasa, untuk mengadakan perkumpulan yang resmi dan diakui, mengajar di sekolah negeri, bebas dari penyadapan, dan bersosialisasi dengan orang lain (Sullivan dkk., 1979).

Bentuk intoleransi tidak hanya meliputi pembatasan hak sipil, intoleransi juga dapat menghasilkan prasangka, kebencian, hingga tindakan diskriminasi antarkelompok (Sullivan dkk., 1981). Bentuk intoleransi yang paling lumrah dalam praktik demokrasi adalah penentangan hak-hak sipil terhadap kelompok yang tidak disukai, seperti tidak memperbolehkan kandidat yang berasal dari kelompok agama, ras, atau etnis tertentu untuk berpartisipasi dalam pemilihan umum. Apabila dikaitkan dengan fenomena yang telah dibahas pada pendahuluan, bentuk intoleransi politik ini yang sedang terjadi di Indonesia. Dalam dunia demokrasi, perlu adanya keadilan terhadap setiap kelompok untuk memenuhi hak-haknya sebagai warga negara. Kebijakan publik maupun norma tidak tertulis yang membatasi atau menentang hakhak sebagian atau pihak tertentu untuk memenuhi hak sebagai warga sipil merupakan bentuk intoleransi politik (Sullivan dkk., 1981).

Pengukuran konvensional toleransi diukur sebagai kesediaan untuk memperbolehkan hak sipil terhadap kelompok yang paling tidak disukai responden. Secara gamblang, toleransi di dalam praktik demokrasi mengharuskan seluruh kelompok untuk menyelenggarakan, mengubah pendapat, serta mengawasi kinerja pemerintah (Gibson \& Gouws, 2000). Gibson (1988) juga menegaskan bahwa toleransi bukan berarti bersikap permisif, namun memberikan hak kepada lawan politik dalam kompetisi memperoleh kekuasaan. Dengan demikian, di dalam setiap kondisi yang mengandung pembatasan hak untuk berpartisipasi dalam politik, nilai-nilai demokrasi belum seutuhnya diterapkan karena sikap dan tingkah laku intoleran masih terjadi.

Dalam studi yang berjudul The Sources of Political Tolerance: A Multivariate Analysis, Sullivan dkk. (1981) membagi variabel-variabel yang memprediksi intoleransi politik menjadi tiga kategori, yaitu: (1) determinan sosial, (2) determinan psikologis; (3) determinan politik. Determinan sosial meliputi usia, status sosial, tingkat pendidikan, dan keberagamaan. Determinan psikologis meliputi variabel-variabel kepribadian seperti self-esteem, aktualisasi nilai, dogmatisme agama, serta kepercayaan pada orang lain. Sementara itu, determinan politik mencakup konservatisme, norma-norma umum, dan persepsi terhadap ancaman.

Dalam studinya, Hazama (2010) menyebutkan beberapa determinan 
kontekstual atau faktor eksternal yang dapat memprediksi intoleransi di antaranya adalah sistem kenegaraan, kebijakan publik, dan keberagaman etnis. Berdasarkan hasil studi literatur Hazama (2010), dibutuhkan studi lanjutan yang mengkaji faktor psikologis dan nonpsikologis seperti perbedaan status sosial-ekonomi dan penggunaan atribut agama sebagai manifestasi pengaruh agama terhadap intoleransi politik.

Dalam studi lain, Eisenstein (2006) menemukan bahwa variabel agama secara tidak langsung dapat meningkatkan intoleransi karena komitmen agama dapat memperkuat persepsi ancaman, sedangkan doktrin ortodoks membuat closed-mindedness (ketertutupan pikiran) meningkat dan dapat menurunkan selfesteem (kepercayaan diri). Penelitian Eisenstein (2006) juga menunjukkan bahwa religiusitas dapat membuat seseorang lebih intoleran. Temuan ini dijelaskan melalui salah satu aspek pada religiusitas yaitu doktrin agama yang membuat individu religius lebih kaku sehingga lebih intoleran. Studi mengenai hubungan antara agama dan intoleransi belum banyak dilakukan sehingga penting untuk mengetahui hubungan antara variabel agama dengan intoleransi di negara yang religius seperti Indonesia. Padahal di Indonesia agama merupakan salah satu faktor yang menentukan perilaku politik seseorang. Penelitian mengenai intoleransi juga masih berfokus di Amerika Serikat dan negara-negara di Eropa, sehingga belum banyak dilakukan di negara yang menerapkan demokrasi pada sistem pemerintahan seperti Indonesia.

Religiusitas Islam. Gibson (2010) mendefinisikan religiusitas sebagai perbedaan individual dalam hal ketertarikan atau keterlibatan seseorang dalam agama tertentu. Perbedaan individu ini meliputi perbedaan sikap, kognisi, emosi, dan tingkah laku dalam beragama. Religiusitas dapat diukur atau diamati sebagai variabel kontinu dan dapat dikategorikan sebagai religius maupun kurang atau tidak religius (Gibson, 2010). Allport dan Ross (1967) mengartikan religiusitas sebagai orientasi seseorang dalam beragama. Misalnya, seseorang yang memiliki orientasi intrinsik beragama untuk pengembangan spiritual, panduan, dan mencari makna kehidupan, sedangkan seseorang individu yang memiliki orientasi ekstrinsik beragama untuk kepentingan mendapatkan dukungan atau pengakuan sosial.

Glock (1962) mendefinisikan religiusitas sebagai derajat keyakinan (belief) terhadap agama, rasa kepemilikan (belonging), dan perilaku (behavior) dalam mengamalkan ajaran-ajaran agama tertentu. Sementara itu, religiusitas Islam didefinisikan oleh El-Menouar (2014) sebagai keimanan atau kepercayaan seorang penganut agama Islam (Sunni) atau Muslim terhadap lima rukun Islam dan rukun Iman serta perilaku dalam mengamalkan ajaran-ajaran agama. Dalam penelitian ini, religiusitas Islam diartikan sebagai keyakinan terhadap ajaran Islam dan perilaku seorang Muslim dalam beragama.

El-Menouar (2014) mengadopsi dimensi religiusitas Glock (1962) untuk menjelaskan religiusitas Muslim. ElMenouar (2014) membagi religiusitas Islam menjadi lima dimensi, yaitu basic religiosity, central religious duties, religious experience, religious knowledge, dan orthopraxis.

Basic Religiosity. Dimensi ini mencakup hal-hal yang terkait dengan keyakinan atau keimanan dan praktik-praktik penyembahan terhadap agama Islam. Dalam Islam, keimanan terhadap agama tidak dapat dipisahkan dari praktik agama itu sendiri. Keyakinan dalam agama Islam disebut dengan istilah Iman. Iman diartikan sebagai keyakinan atau perasaan bahwa Allah SWT hadir di mana-mana. Oleh karena itu, iman semestinya diikuti oleh penyembahan melalui ritual-ritual wajib maupun sunnah (dianjurkan tetapi tidak wajib).

Central Religious Duties. Dimensi central religious duties mencakup lima 
pilar agama Islam atau rukun Islam, yaitu mendirikan salat, berpuasa pada bulan Ramadan, dan menunaikan ibadah haji. Seperti yang telah dibahas sebelumnya, norma-norma ini merupakan ritual ibadah berupa perilaku yang dapat diamati dalam kehidupan sehari-hari. Dimensi basic religiosity yang berfokus pada kesalehan seorang Muslim, sementara itu dimensi central religious duties menjelaskan kewajiban dalam beragama yang berfokus pada kesalehan seorang Muslim secara kolektif atau pada tingkat sosial. Kewajiban beragama yang dimaksud dalam dimensi ini memiliki kesamaan karakteristik, yaitu ibadah yang dilakukan bersama-sama dengan Muslim lainnya. Selain itu, dimensi ini juga menjelaskan ibadah-ibadah dalam Islam yang bersifat universal sehingga berbeda dengan kesalehan ortodoks.

Religious Experience. Dalam teori religiusitas, Stark (1965) membedakan pengalaman beragama yang mengukuhkan keimanan dan kewajiban sebagai penganut agama. Butir pernyataan dalam dimensi ini meliputi pengalaman beragama individu yang sangat personal dan tidak sebatas kewajiban yang dianjurkan oleh agama. Menurut El-Menouar (2014), kekuatan iman atau kesalehan seorang penganut agama tidak hanya diukur dari kepatuhannya terhadap kewajiban dan larangan agama. Oleh karena itu, pengalaman religius seperti merasa berinteraksi langsung dengan Yang Maha Kuasa perlu diukur secara terpisah dari dimensi lainnya.

Pengetahuan Religius. Menurut Glock (1962), individu yang religius semestinya memiliki pengetahuan dan pemahaman informasi terkait agama yang dianut. Pengetahuan terkait agama dapat dilihat melalui literasi penganut terhadap kitab suci atau ajaran-ajaran yang para pemuka agama (Glock, 1962). Dalam Islam, sumber pengetahuan agama adalah Al-Qur'an dan hadis (El-Menouar, 2014). Oleh karena, pengetahuan seorang Muslim tentang Islam dapat dilihat atau diukur melalui pemahaman- nya tentang Al-Qur'an dan ajaran-ajaran Nabi Muhammad SAW.

Orthopraxis. Dalam setiap agama biasanya telah dikemukakan dampak dari perilaku atau praktik agama secara eksplisit maupun implisit (Glock, 1962). Orthopraxis dalam Islam merupakan ajaran-ajaran Islam yang bersifat ortodoks atau ketat (El-Menouar, 2014). Islam mempengaruhi setiap sendi kehidupan penganutnya sehingga setiap aktivitas merupakan bentuk penghambaan umat Islam kepada Allah SWT (El-Menouar, 2014). Penerapan Islam dalam kehidupan sehari-hari di luar ritual keagamaan yang bersifat wajib dapat menjadi pembeda tingkat kesalehan dalam kalangan umat Muslim. Dimensi orthopraxis mencakup ajaran-ajaran Islam sebagai representasi norma-norma sosial yang diatur, misalnya interaksi antara laki-laki dan perempuan serta konsumsi makanan dan minuman halal. Religiusitas dapat diukur dari seberapa teguh seorang Muslim menerapkan ajaran Islam dalam kehidupan sehari-hari. Perbedaan dalam penerapan ajaran-ajaran Islam dalam kehidupan sehari-hari dapat merupakan manifestasi dari beragam tingkat religiusitas.

Kepercayaan Politik. Pentingnya kepercayaan dalam konteks sosial politik telah banyak dibahas oleh filsuf seperti Locke dan Tocqueville hingga peneliti kontemporer seperti Putnam (Newton, 2001). Dalam hidup sebagai warga negara demokrasi, kepercayaan merupakan elemen yang penting karena dalam hidup bernegara warga negara yang memiliki kepercayaan atau trust lebih tinggi terhadap masyarakat maupun lembaga pemerintahan akan terlibat dalam aktivitas sosial maupun politik. Newton (2001) mendefinisikan kepercayaan politik sebagai keyakinan seseorang bahwa pejabat publik tidak akan atau tidak berniat untuk melakukan hal-hal yang merugikan rakyat serta tidak bertindak sesuai kepentingannya. Newton (2001) juga mengartikan kepercayaan politik sebagai kepercayaan rakyat terhadap pemerintah dan institusi politik. Kurangnya ke- 
percayaan politik dipahami sebagai celah antara ekspektasi rakyat dan performa pemerintah sebagai pejabat publik. Sementara itu, Hardin (1998) mengartikan kepercayaan politik sebagai keyakinan bahwa pejabat publik mampu menjaga stabilitas sosial dan berperforma optimal dalam menjalankan perannya.

Kepercayaan merupakan komponen utama dari modal sosial yang penting untuk menjaga stabilitas demokrasi. Oleh karena itu, dalam konteks negara demokrasi kepercayaan politik merupakan aspek yang penting untuk diperhatikan maupun dikaji secara ilmiah. Kepercayaan politik sangat dipengaruhi oleh hal-hal dari luar diri seseorang. Stabilitas ekonomi, reputasi pejabat publik, dan konflik sosial merupakan contoh dari aspek yang dapat membuat kepercayaan politik naik atau turun (Newton, 2001). Kepercayaan politik berkaitan dengan variabel politik seperti minat terhadap dunia politik, kepercayaan terhadap pemerintah, dan kebanggaan terhadap negara.

Kepercayaan politik juga dihubungkan dengan kewarganegaraan, partisipasi politik, dan toleransi politik. Newton (2001) juga menambahkan bahwa kepercayaan politik merupakan penilaian atau evaluasi terhadap kondisi politik. Kepercayaan politik menunjukkan penilaian individu sebagai warga di wilayah tertentu (negara maupun kota). Oleh karena itu, kepercayaan politik dapat didefinisikan sebagai keyakinan rakyat terhadap kinerja pejabat publik maupun institusi pemerintahan.

Grimmelikhuijsen dan Knies (2015) membagi kepercayaan politik ke dalam tiga aspek atau dimensi, yaitu perceived competence, perceived benevolence, dan perceived integrity. Perceived competence merupakan persepsi rakyat terhadap kemampuan pemerintah atau pelayan publik untuk melaksanakan perannya secara efektif, terampil, dan profesional. Dimensi perceived benevolence merupakan persepsi rakyat bahwa pemerintah atau pelayan publik peduli terhadap kesejahteraan rakyat dan termotivasi untuk mengambil tindakan atau kebijakan atas kepentingan rakyat. Sementara perceived integrity merupakan persepsi rakyat bahwa pemerintah atau pelayan publik yang terpilih tulus, jujur, dan memenuhi janji-janji politiknya.

Putnam (2000) menemukan bahwa individu yang lebih religius akan memiliki kepercayaan lebih tinggi terhadap lingkungan sekitarnya. Uslaner (2000) juga menambahkan bahwa individu yang religius memiliki tingkat kepercayaan partisipasi dalam pemerintahan yang lebih tinggi.

Religiusitas berkaitan dengan intoleransi politik (Eisenstein \& Clark, 2014). Berdasarkan temuan itu, dalam penelitian ini religiusitas Islam dapat menjadi prediktor intoleransi politik. Semakin tinggi tingkat religiusitas Islam individu, maka intoleransi politik juga akan meningkat. Hubungan antara religiusitas Islam dan intoleransi politik diasumsikan dapat dipengaruhi oleh kepercayaan politik seseorang terhadap pemerintah. Oleh karena itu, kepercayaan politik dapat menjadi moderator pada pengaruh religiusitas Islam terhadap intoleransi politik.

\section{Metode Penelitian}

Studi ini bertujuan untuk mengetahui hubungan antara religiusitas Islam dan intoleransi politik dengan kepercayaan politik sebagai variabel yang dapat memoderasi hubungan keduanya. Berdasarkan tujuan tersebut, penelitian ini termasuk penelitian korelasional dengan pendekatan kuantitatif (Gravetter \& Forzano, 2012). Responden dalam penelitian ini merupakan Warga Negara Indonesia (WNI) yang saat ini sedang menempuh pendidikan jenjang $\mathrm{S} 1$ dan D4, dan beragama Islam. Peneliti menggunakan teknik pengambilan sampel non-probability sampling, yaitu convenience sampling, yaitu sampel dipilih berdasarkan kesediaan individu untuk menjadi responden penelitian (Gravetter \& Forzano, 2012). 


\section{Tabel 1. Hasil Analisis Regresi Linear Variabel Religiusitas Islam, Kepercayaan Politik, dan Intoleransi Politik}

\begin{tabular}{lccccc}
\hline & $\boldsymbol{\beta}$ & $r$ & $r^{2}$ & Adjusted $r^{2}$ & p. \\
\hline Religiusitas Islam & 0,107 & 0,107 & 0,011 & 0,010 & $0,003^{* *}$ \\
Kepercayaan Politik & $-0,032$ & 0,032 & 0,001 & 0,000 & 0,373
\end{tabular}

${ }^{* *}$ signifikan

Instrumen yang digunakan dalam penelitian ini terdiri dari alat ukur intoleransi politik yaitu Political Intolerance Scale yang dikembangkan oleh Gibson (1985), alat ukur religiusitas Islam yaitu Muslim Religiosity Scale yang dikembangkan oleh El-Menouar (2014), serta alat ukur kepercayaan politik yaitu Citizen Trust in Government Organizations (CTGO) Scale yang disusun oleh Grimmelikhuijsen dan Knies (2015). Alat ukur intoleransi politik sebelumnya telah diadaptasi oleh Putra (2007) ke dalam Bahasa Indonesia, namun peneliti melakukan uji coba untuk mengetahui reliabilitas dan validitas alat ukur ini. Alat ukur kepercayaan politik yaitu CTGO juga telah diadaptasi oleh Wahyudi (2016). Peneliti melakukan adaptasi pada alat ukur religiusitas Islam ke dalam Bahasa Indonesia, lalu melakukan uji coba alat ukur. Uji reliabilitas terhadap alat ukur intoleransi politik menggunakan Cronbach Alpha dan memperoleh koefisien alpha 0,8 . Item-item pada alat ukur intoleransi politik memiliki konsistensi internal yang berkisar pada 0,415-0,846. Berdasarkan uji reliabilitas terhadap alat ukur Muslim Religiosity dengan Cronbach Alpha diperoleh koefisien alpha 0,846. Hasil uji reliabilitas terhadap alat ukur CTGO dengan Cronbach Alpha 0,914. Konsistensi internal seluruh item pada alat ukur berkisar antara $r=0,449-0,786$.

Penjaringan responden penelitian ini dilakukan secara online (daring) dengan menyebarkan tautan kuesioner yang telah disusun pada platform Google Form. Peneliti menyebarkan informasi pen- jaringan responden melalui berbagai media sosial (Line, Whatsapp, Facebook, dan Instagram). Setiap responden memiliki kesempatan untuk mendapat reward pulsa senilai Rp 25.000 yang diundi masing-masing untuk 20 responden. Melalui proses penjaringan responden penelitian, peneliti memperoleh 841 responden. Namun, setelah melakukan penyaringan data peneliti akhirnya menggunakan data dari 809 responden untuk diolah. Peneliti juga melakukan uji normalitas data dengan teknik ShapiroWilk lalu uji stem and leaf untuk mengetahui skor ekstrim pada tiap variabel. Setelah melakukan eliminasi pada skor ekstrim, peneliti memperoleh data 753 responden untuk dianalisis lebih lanjut.

\section{Hasil Penelitian}

Untuk mengetahui hubungan religiusitas Islam dan intoleransi politik, peneliti melakukan uji regresi linear. Berdasarkan analisis regresi linear ditemukan religiusitas Islam memiliki korelasi positif dan signifikan dengan intoleransi politik $(r$ $=0,107, p<.01$, two-tailed). Hasil analisis juga menunjukkan bahwa religiusitas Islam $(\beta=0,107)$ lebih kuat dalam menjadi prediktor dari intoleransi politik dibanding kepercayaan politik $(\beta=0,032)$. Apabila melihat nilai $r^{2}$ pada religiusitas Islam $r^{2}=$ 0,01 yang menunjukkan bahwa $1,1 \%$ varians skor intoleransi politik ditentukan oleh religiusitas Islam, sedangkan kepercayaan politik dengan $r^{2}=0,001$ menunjukkan bahwa $0,1 \%$ varians skor intoleransi politik ditentukan oleh kepercayaan politik. 
Tabel 2. Hasil Penghitungan Korelasi antara Dimensi dari Religiusitas Islam dan Intoleransi Politik

\begin{tabular}{lccc}
\hline & Intoleransi Politik $(r)$ & $p$ & $r^{2}$ \\
\hline Basic Religiosity & 0,063 & 0,086 & 0,0039 \\
Central Duties & -0.049 & 0,183 & 0,0024 \\
Experience & $-0,123$ & $0,001^{* *}$ & 0,0151 \\
Knowledge & $-0,020$ & 0,593 & 0,0004 \\
Orthopraxis & 0,180 & $0,000^{* *}$ & 0,0324 \\
\hline
\end{tabular}

Tabel 3. Analisis Efek Moderasi Kepercayaan Politik terhadap Hubungan Religiusitas Islam dan Intoleransi Politik

\begin{tabular}{lcccc}
\hline & $r$ & $r^{2}$ & $r^{2}$ Change & $p$ \\
\hline Model 1 & 0,1277 & 0,0163 & 0,0035 & 0,1025 \\
$\begin{array}{l}\text { Religiusitas Islam * Kepercayaan } \\
\text { Politik }\end{array}$ & & & & \\
\hline
\end{tabular}

Peneliti juga menghitung korelasi tiap dimensi religiusitas Islam dengan intoleransi politik. Berdasarkan hasil penghitungan korelasi antara dimensidimensi religiusitas Islam dan intoleransi politik, ditemukan bahwa terdapat hubungan negatif yang signifikan antara dimensi experience dan intoleransi politik $(r$ $=-0,123, \mathrm{n}=753, p<.01$, two-tailed) serta terdapat hubungan positif yang signifikan antara dimensi orthopraxis dan intoleransi politik $(r=0,180, \mathrm{n}=753, p<$ .01 , two-tailed). Sementara itu, tidak terdapat hubungan yang signifikan antara dimensi basic religiosity dan intoleransi politik $(r=0,063, \mathrm{n}=753, p>.05$, twotailed), dimensi central duties dan intoleransi politik $(r=-0,049, \mathrm{n}=753, p>.05$, two-tailed), serta dimensi knowledge dan intoleransi politik $(r=-0,020, \mathrm{n}=753, p>$ .05, two-tailed).

Peneliti juga menghitung nilai koefisien determinan pada dimensi religiusitas Islam yang memiliki korelasi signi- fikan dengan intoleransi politik. Pada dimensi experience nilai $r^{2}=0,0151$, sehingga dapat disimpulkan bahwa 1,51\% varians skor intoleransi politik dapat dijelaskan oleh dimensi experience. Pada dimensi orthopraxis $r^{2}=0,0324$, sehingga dapat disimpulkan bahwa $3,24 \%$ varians skor intoleransi politik dapat dijelaskan oleh dimensi orthopraxis.

Kemudian, untuk mengetahui efek moderasi kepercayaan politik terhadap hubungan antara religiusitas Islam dan intoleransi politik, peneliti melakukan analisis efek moderasi menggunakan PROCESS for SPSS by Andrew F. Hayes. Dalam analisis efek moderasi menggunakan Hayes PROCESS, mean centering telah otomatis dilakukan. Berdasarkan analisis efek moderasi, diketahui bahwa kepercayaan politik memiliki efek moderasi yang tidak signifikan terhadap korelasi antara religiusitas Islam dengan intoleransi politik $(r=0,0035, \mathrm{n}=753, p>$ .05 , two-tailed). Selain itu, perubahan 
$r^{2}=0,0035$ menunjukkan bahwa kepercayaan politik mengubah nilai $r$ sebesar $0,35 \%$ terhadap korelasi religiusitas Islam dan intoleransi politik. Dengan demikian, $\mathrm{Ho}_{2}$ penelitian ini gagal ditolak.

\section{Diskusi}

Hasil penelitian ini menguatkan hasil studi sebelumnya (Eisenstein \& Clark, 2014) bahwa religiusitas dapat menjadi prediktor dari intoleransi politik. Walaupun terdapat korelasi yang signifikan antara religiusitas Islam dan intoleransi politik, hasil penghitungan $r^{2}$ menunjukkan bahwa varians skor religiusitas Islam menentukan $1 \%$ varians skor intoleransi politik. Menurut Field (2009), effect size 1\% merupakan varians yang dikategorikan effect size kecil dalam memprediksi variabel dependen. Hasil tersebut menjelaskan bahwa religiusitas Islam dapat memprediksi intoleransi politik pada responden, walaupun efeknya kecil.

Temuan ini mengonfirmasi temuan studi Eisenstein (2006) menyebutkan bahwa keberagamaan membuat seseorang lebih tidak menerima kelompok yang tidak disukainya terutama jika kelompok itu disebut dalam perintah agama. Hal ini dapat terjadi karena individu yang demikian telah terdoktrin oleh agama sehingga cenderung lebih intoleran (Eisenstein, Clark, \& Clark, 2014). Studi-studi toleransi politik juga menemukan bahwa orang komitmen seseorang terhadap agama dalam bentuk perilaku beribadah membuat seseorang lebih tidak menerima orang lain (Stouffer, 1955; Sullivan dkk., 1981).

Hasil penelitian ini juga menunjukkan bahwa kepercayaan politik tidak signifikan sebagai variabel moderator pada hubungan antara religiusitas Islam dan intoleransi politik. Peran kepercayaan politik yang tidak signifikan dapat dipengaruhi oleh fenomena yang terjadi pada saat penelitian dilakukan. Isu agama saat penelitian ini dilakukan menjadi fenomena yang sangat menonjol. Penjelasan lain yang dapat menjabarkan mengapa kepercayaan politik tidak ber- peran hubungan antara kedua variabel adalah kepercayaan politik diatribusikan terhadap pemerintah yang sedang menjabat pada masa itu. Sementara, intoleransi politik diatribusikan pada kelompok minoritas yang sedang menjabat maupun akan menjabat di pemerintahan.

Selain itu, peneliti juga melihat korelasi tiap dimensi religiusitas Islam dengan intoleransi politik. Hasil analisis menunjukkan bahwa terdapat dua dari lima dimensi religiusitas Islam yang memiliki korelasi signifikan dengan intoleransi politik, yaitu dimensi experience dan dimensi orthopraxis. Dimensi experience mengukur pengalaman religius seorang Muslim seperti merasa berinteraksi langsung dengan Allah SWT. Dimensi experience berkorelasi negatif secara signifikan dengan intoleransi politik yang artinya semakin seorang Muslim merasakan pengalaman yang lebih dalam seperti merasa berinteraksi dengan Allah SWT, maka individu tersebut akan memiliki skor intoleransi politik yang rendah atau dapat dikatakan lebih toleran.

Temuan ini sesuai dengan penemuan studi Verkuyten, Maliepaard, Martinovic, dan Khoudja (2014) bahwa terdapat korelasi positif antara religiusitas dan toleransi, yang dapat disimpulkan bahwa semakin tinggi religiusitas seseorang maka ia akan semakin toleran. El-Menouar (2014) menambahkan penjelasan terhadap temuan penelitian ini bahwa seorang Muslim yang merasakan interaksi dengan Allah SWT tidak sebatas menjalankan perintah agama dan memahami bahwa Allah SWT juga memerintahkan Muslim untuk bersikap toleran terhadap sesama manusia. Temuan riset ini juga memperjelas dimensi dari religiusitas yang berkontribusi pada intoleransi.

Selain itu, analisis dalam penelitian ini menunjukkan bahwa terdapat korelasi positif yang signifikan antara dimensi orthopraxis dan intoleransi politik. Artinya, semakin tinggi skor responden pada dimensi orthopraxis yang mengukur sejauh mana seorang Muslim menerapkan 
ajaran Islam dalam kehidupan sehari-hari maka intoleransi politiknya akan meningkat. El-Menouar (2014) menyimpulkan bahwa dimensi orthopraxis merupakan dimensi yang setara dengan ajaran ortodoks dalam agama lain. Hasil ini juga diperkuat oleh temuan Neiheisel, Djupe, dan Sokhey (2009) bahwa individu yang memiliki pengalaman beragama yang lebih kuat akan cenderung lebih intoleran, terutama ketika religiusitas seorang penganut agama membuat individu tertutup dan menyendiri sehingga ia tidak terpapar keyakinan lain atau keberagaman ideologi. Walaupun demikian, agama secara umum maupun Islam sendiri tidak memerintahkan umatnya untuk intoleran, tetapi orang-orang yang terpaku pada dogma agama akan lebih menyetujui untuk tidak memberikan hak-hak politik kepada kelompok yang tidak disukai.

Toleransi politik merupakan langkah penting dalam hidup bersama untuk mencegah terjadinya diskriminasi, permusuhan, dan menciptakan kondisi demokrasi yang stabil (Sullivan \& Transue, 1999). Prinsip ini merupakan landasan untuk menerima perbedaan pandangan, keyakinan, maupun identitas agar demokrasi dapat berlangsung secara sehat. Di sisi lain, agama semestinya dapat mendorong toleransi dengan paparan keberagaman umat beragama dan membantu umat beragama untuk membangun relasi dengan orang lain di luar penganut agama (Djupe \& Calfano, 2012). Temuan penelitian ini menjelaskan bahwa religiusitas Islam dapat memprediksi toleransi maupun intoleransi politik. Dimensi-dimensi dalam religiusitas Islam memiliki arah hubungan yang berbeda dengan intoleransi politik, sehingga dapat disimpulkan bahwa dimensi yang berkorelasi negatif dan signifikan, yaitu dimensi experience dapat menjadi faktor protektif terhadap intoleransi politik.

\section{Kesimpulan}

Terdapat korelasi yang positif dan signifikan antara religiusitas Islam dan intoleransi politik. Korelasi positif menun- jukkan bahwa semakin tinggi skor religiusitas Islam, maka semakin tinggi pula skor intoleransi politik pada responden. Selain itu, terdapat dua dimensi religiusitas Islam, yaitu dimensi experience yang memiliki korelasi negatif dan signifikan dengan intoleransi politik serta dimensi orthopraxis yang memiliki korelasi positif dan signifikan dengan intoleransi politik Sementara itu, kepercayaan politik tidak memiliki hubungan yang signifikan dengan intoleransi politik. Hasil analisis efek moderasi menunjukkan bahwa kepercayaan politik tidak berperan sebagai variabel moderator terhadap hubungan religiusitas Islam dan intoleransi politik.

Saran. Dalam penelitian ini ditemukan bahwa alat ukur intoleransi politik dalam penelitian ini merupakan hasil adaptasi alat ukur intoleransi politik yang dibuat dengan konteks sosial politik di Amerika Serikat. Di penelitian selanjutnya disarankan untuk menyusun alat ukur intoleransi politik yang sesuai dengan konteks di Indonesia. Alat ukur intoleransi politik yang ada saat ini merupakan alat ukur yang dibuat berdasarkan kondisi sosial politik di luar negeri sehingga terdapat beberapa item yang tidak sesuai dengan kondisi di Indonesia. Selain itu, peneliti nanti perlu memperhatikan social desirability pada item-item alat ukur mengingat isu intoleransi cukup sensitif.

Intoleransi politik merupakan konstruk yang penting untuk diperhatikan dalam negara demokrasi yang plural karena indikasi bahwa sistem demokrasi berjalan dengan lancar adalah warga negara yang memiliki toleransi politik. Oleh karena itu, penelitian selanjutnya perlu mengkaji variabel-variabel psikologis lain seperti variabel kognitif hingga kepribadian yang berpotensi menjadi prediktor dari intoleransi politik.

Sebagai sebuah negara yang didominasi oleh warga negara beragama, variabel agama perlu diteliti kembali sebagai salah satu prediktor intoleransi politik di Indonesia. Intoleransi politik 
merupakan variabel yang multikausal sehingga peneliti selanjutnya perlu menambahkan variabel-variabel lain dalam penelitian untuk melihat variabel lain yang dapat memprediksi intoleransi politik. Dengan demikian, intoleransi politik perlu dilihat tidak hanya sebagai fenomena melainkan sebagai konstruk psikologis yang dapat diteliti secara ilmiah. Penelitian intoleransi politik yang lebih komprehensif dapat membantu ilmuwan maupun praktisi psikologi politik untuk menguraikan masalah intoleransi politik di Indonesia.

\section{Daftar Referensi}

Allport, G. W. \& Ross, J. (1967). Personal religious orientation and prejudice. Journal of Personality and Social Psychology, 5(4), 432-443. doi: 10.1037/0022-3514.5.4.432

Altemeyer, B. (1988). Enemies of freedom. San Francisco: JosseyBass.

Beyerlein, K. \& Hipp, J. R. (2006). From pews to participation: the effect of congregation activity and context on bridging civic engagement. Social Problems, 53(1), 97-117. doi: 10.1525/sp.2006.53.1.97

Djupe, P. A., \& Calfano, B. R. (2012). American Muslim investment in civil society: Political discussion, disagreement, and tolerance. Political Research Quarterly, 65(3), 516-528. doi:10.1177/1065912911401417

Eisenstein, M. A (2006). Rethinking the relationship between religion and political tolerance in the U.S. Political Behavior, 28(4), 327-348. doi: $10.1007 / \mathrm{s} 11109-006-9014-5$

Eisenstein, M. A. \& Clark, A. K. (2014). Political tolerance, psychological security, and religiosity: disaggregating the mediating influence of psychological security. Politics and Religion, 7(2), 287-317. doi: $10.1017 / \mathrm{s} 1755048314000054$

Eisenstein, M., \& Clark, A. (2017). Explaining differing democratic norm commitment: Rethinking the religionpsychological security-democratic norm support connection. Politics and Religion, 10(4), 753-785. doi: 10.1017/S175504831700030X

El-Menouar, Y. (2014). The five dimensions of Muslim religiosity: results of an empirical study. Methods, Data, Analyses: A Journal for Quantitative Methods and Survey Methodology. 8(1), 53-78. doi: $10.12758 /$ mda.2014.003

Field, A. (2009). Discovering statistics using SPSS. Sage publications.

Gibson, G. L., \& Bingham, R.D. (1982). On the conceptualization and measurement of political tolerance. American Political Science Review, 76(3), 603-620. doi: 10.2307/1963734

Gibson, J. L. (1988). Political intolerance and Political repression during the mcCarthy red Scare. American Political Science Review, 8(2), 511529. doi: $10.2307 / 1957398$

Gibson, J. (2013). Political intolerance in the context of democratic theory. Oxford Handbooks Online. Retrieved from http://www.oxfordhandbooks.com/ view/10.1093/oxfordhb/9780199604 456.001.0001/oxfordhb9780199604456-e-021.

Gibson, J. L. (2010). The political consequences of religiosity: does religion always cause political intolerance?" In A. Wolfe \& I. Katznelson (Eds), Religion and Democracy in America: Danger or Opportunity? pp. 147-175. New York and Princeton, NJ: Russell Sage Foundation and Princeton University Press.

Gibson, J. L. (2013). Measuring political tolerance and general support for pro-civil liberties policies: Notes, evidence, and cautions. Public Opinion Quarterly, 77 (Special Issue), 45-68. doi: 10.1093/poq/nfs073

Gibson, J., \& Gouws, A. (2000). Social identities and political intolerance: Linkages within the South african mass public. American Journal of 
Political Science, 44(2), 278-292. doi:10.2307/2669310

Glock, C. Y. (1962). On the study of religious commitment. Religious Education: The Official Journal of the Religious Education Association, 57(S4), 98-110. doi: 10.1080/ $003440862057 s 407$

Gravetter, F. J. \& Forzano, L. B. (2012). Research methods for the behavioral sciences. Wadsworth: Cengage Learning

Grimmelikhuijsen, S. \& Knies, E. (2015). Validating a scale for citizen trust in government organizations. International Review of Administrative Sciences, 83(3), 583-601. doi: $10.1177 / 0020852315585950$

Haas, I. J. \& Cunningham, W. A. (2014). The uncertainty paradox: Perceived threat moderates the effect of uncertainty on political tolerance. Political Psychology, 35(2), 291302. doi:10.1111/pops.12035

Hardin. R. (1998). Trust in Government. In Trust and Governance (V. Braithwaite and M. Levi, eds.), pp. 9-27. New York: Russell Sage.

Hazama, Y. (2010). Determinants of political tolerance: A literature review. IDE discussion paper, 288 Chiba: Institute of Developing Economies. Retrieved from http://www.ide.go.jp/English/Publish/ Down load/Dp/pdf/288.pdf

Hinckley, R. A. (2010). Personality and political tolerance: The limits of democratic learning in postcommunist Europe. Comparative Political Studies, 43(2), 188-207. doi: 10.1177/0010414009349327

Levi, M. \& Stoker, L. (2000). Political Trust and Trustworthiness. Annual Review of Political Science, 3(1), 475-507. doi: 10.1146/annurev. polisci.3.1.475.

Marcus, G. E., Sullivan, J. L., TheissMorse, E., \& Wood, S. L. (1995). With malice toward some: how people make civil liberties judg- ments. Cambridge, MA: Cambridge University Press.

McClosky, H., \& Brill, A. (1983). Dimensions of tolerance. New York, NY: Russell Sage Foundation.

Nannestad, P. (2008). What have we learned about generalized trust, if anything? Annual Review of Political Science, 11(1). 413-36. doi: 10.1146/annurev.polisci.11.060606. 135412

Neiheisel, J. R., Djupe, P. A. \& Sokhey, A. E. (2009). Veni, Vidi, Disseri: Churches and the promise of democratic deliberation. American Politics Research, 37(4), 614-43. doi: $10.1177 / 1532673 \times 08324216$

Newton, K. (2001). Trust, Social Capital, Civil Society, and Democracy. International Political Science Review/ Revue Internationale De Science Politique, 22(2), 201-214. Retrieved from http://www.jstor.org/stable/ 1601186

Nye, J. S., Zelikow, P.D., \& King, D.C. (1997). Why People Don't Trust Government. Cambridge: Harvard University Press.

Protho, J. W. \& Grigg, C. M. (1960). Fundamental principles of democracy: A basis of agreement and disagreement. The Journal of Politics, 22(2), 276-294. doi: $10.2307 / 2127359$

Putnam, R. D. (2000). Bowling alone: the collapse and revivial of American community. New York: Simon \& Schuster.

Putra, I. E. (2007). Pengaruh orientasi keberagamaan, ideologi politik, fundamentalisme, dan orientasi dominasi sosial terhadap intoleransi politik. Depok: Universitas Indonesia.

Saroglou, V., Delpierre, V., \& Dernelle, R. (2004). Values and religiosity: A meta-analysis of studies using Schwartz's model. Personality and Individual Differences, 37(4), 721734. doi: 10.1016/j.paid.2003.10.005

Stark, R. (1965). A taxonomy of religious experience. Journal for the Study of 
Religion, 5(1), 97-116. doi: $10.2307 / 1384259$

Stouffer, S. A. (1955). Communism, conformity and civil liberties. New York, NY: John Wiley.

Sullivan, J. L. \& Transue. J. E (1999). The psychological underpinnings of democracy: A selective review on research on political tolerance, interpersonal trust, and social capital. Annual Review of Psychology, 50(1), 625-650. doi: 10.1146/annurev.psych.50.1.625

Sullivan, J. L., Marcus, G. E., Feldman, S., \& Piereson, J. E. (1981). The sources of political tolerance: A multivariate analysis. The American Political Science Review 75:92-106. doi: $10.2307 / 1961119$

Sullivan, J. L., Piereson, J. E., \& Marcus, G. E. (1979). An alternative conceptualization of political tolerance: Illusory increases 1950s1970s. The American Political Science Review, 73(2), 781-794. doi: $10.2307 / 1955404$

Uslaner, E. M. (2000). Producing and consuming trust. Political Science Quarterly, 115(4), 569-590. doi: $10.2307 / 2657610$

Tirto.id. (2017, January 6). Survei: Pesan Intoleransi Bertebaran di Media
Sosial. (M. Saroh, Editor) Retrieved from Tirto.id: https://tirto.id/surveipesan-intoleransi-bertebaran-dimedia-sosial-cfeY.

Verkuyten, M., Maliepaard, M., Martinovic, B., \& Khoudja, Y. (2014). Political tolerance among Muslim minorities in Western europe: the role of denomination and religious and host national identification. Politics and Religion, 7(2), 265-286. doi: $10.1017 / S 1755048314000212$

Wahid Foundation. (2016, August 4). RI Masih Rentan Intoleransi, Wahid Foundation Sampaikan Enam Rekomendasi. Retrieved from http://www.wahidfoundation.org/inde x.php/news/detail/RI-Masih-RentanIntoleransi-Wahid-FoundationSampaikan-Enam-Rekomendasi.

Wahyudi, J. (2016). Persepsi keadilan sosial dan kepercayaan interpersonal sebagai prediktor kepercayaan politik di Indonesia. Depok: Universitas Indonesia.

Welch, M. R., Sikkink, D., Sartain, E., \& Bond, C. (2004). Trust in god and trust in man: The ambivalent role of religion in shaping dimensions of social trust. Journal for the Scientific Study of Religion, 43(3), 317-343. doi: 10.1111/j.1468-5906.2004.00238.x 